\title{
Influence of Overconfidence and Cash Flow on Investment in Vietnam*
}

\author{
Duy Van NGUYEN ${ }^{* *}$, Duong Quy DANG ${ }^{* * *}$, Giang Hoang PHAM ${ }^{* * * *}$, Du Kim DO ${ }^{* * * * *}$
}

Received: October 31, 2019 Revised: December 11, 2019 Accepted: December 18, 2019

\begin{abstract}
CEOs Overconfidence can bring potentially risky early decisions to businesses, along with large enterprise free cash flow that can bring different investment decisions with CEOs Overconfidence. Especially in the context of Vietnamese enterprises, CEOs are often influenced by behavioral psychology about overconfidence in investment decisions (due to individual cultural characteristics as well as operating financial markets also depend on many factors outside the market). Therefore, the authors study the impact of overconfidence and cash flow on investment in Vietnamese to find the internal relationship between these three factors in the financial environment in Vietnam. With 480 companies listed on the Vietnam Stock Exchange from 2014 to 2018 (companies have continuous reports), the regression analysis results with panel data (FEM, GLS models, correction of robust and GMM dealing with endogenous problems) have shown Overconfidence has a positive impact on investment. At the same time, the results also indicated that enterprises with overconfident CEOs and large cash flows tend to invest less than enterprises with low cash flow. The results of this study have shown the behavioral behavior of CEOs in Vietnamese enterprises that exist under both prospect theory and effective market theory.
\end{abstract}

Keywords: Overconfidence, Cash Flow, Investment, Vietnam

JEL Classification Code: B26, C33, G40

\section{Introduction}

In the context of Vietnam's financial market has not developed into a perfectly competitive economy. The investment decisions of enterprise director depend too much on the information element provided by the market (due to data on the market is not enough and transparen. Therefore, information asymmetry often makes inaccurate

*The authors would like to send the gratitude to Prof Laurence Abadie - Lecturer at laelyon School of Management, Université Jean Moulin Lyon 3 for giving the authors valuable contributions in orienting this paper. These guidances have supported we a lot in improving the article's content

${ }^{* *}$ First Author and Corresponding Author. Quantitative Analysis Center, QA Global Co., Hanoi, Vietnam [Postal Address: 9/82 Chua Lang street, Dong Da District, Hanoi, 100000, Vietnam]

Tel: +84.945649731, Email: duynguyen.qa@gmail.com

***University of Economics and Business, Vietnam National University, Hanoi, Vietnam. Email: dangquyduongts@gmail.com

**** Foreign Trade University, Hanoi, Vietnam.

Email: giangpham1497@gmail.com

${ }_{* * * * *}$ Thai Nguyen University of Economics and Business Admini stration, Thai Nguyen city, Vietnam. Email: dokimdu@gmail.com (-) Copyright: Korean Distribution Science Association (KODISA)

This is an Open Access article distributed under the terms of the Creative Commons Attribution NonCommercial License (https://creativecommons.org/licenses/by-nc/4.0/) which permits unrestricted noncommercial use, distribution, and reproduction in any medium, provided the original work is properly cited. decisions for administrators. With the influence of information asymmetry theory will make the director do not want to use external capital by issuing shares (issuing shares will reduce the value of the business) but prefer to use internal cash flow to head private (Akerlof, 1978; Ascioglu, Hegde, \& McDermott, 2008). It is this CEO's view that minimizes overinvestment.

Agency theory suggests that directors tend to overinvestment in achieving personal interests. These targets will to some extent be limited by external capital markets. Therefore, directors will overinvestment based on the company's excess cash resource (Pikulina, Renneboog, $\&$ Tobler, 2017). This issue will cause agency costs for shareholders and reduce corporate value. In cases of overinvestment with high-risk portfolios can lead to default businesses. In addition, decisions of corporate executives in Vietnam are heavily influenced by behavioral psychology. In recent studies, Malmendier and Tate (2005b) has mentioned overconfidence that affects business decisions. Accordingly, optimistic directors often overestimate the return on investment or profitability when the project succeeds. And the directors think their company shares are underestimated. From there they will tend to invest too 
much, which is more than the best (Malmendier \& Tate, 2005b; Pikulina et al., 2017).

Investment decisions are not only affected by Overconfidence but also depend on financial potential such as free cash flow of enterprises. Enterprises with CEOs Overconfidence and large cash flows easily lead to overinvestment (Heaton, 2002; Malmendier \& Tate, 2005a). In contrast, enterprises with low cash flow will limit overinvestment but increase underinvestment affecting firm's value. Many studies have shown the sensitivity of investment to cash flow and Overconfidence (Hackbarth, 2008; Heaton, 2002; Malmendier \& Tate, 2005b). Therefore, considering the impact of cash flow on the investment of businesses with confident CEOs Overconfidence in businesses brings suggestions to adjust investment policies or control the investment.

There have been many studies conducted to assess the impact of Overconfidence on corporate investment taking into account the cash flow factor. In particular, the major studies that show the positive effects of Overconfidence to investment and cash flow tend to increase the impact of Overconfidence on investment (Goel \& Thakor, 2008; Hackbarth, 2008; Heaton, 2002; Malmendier \& Tate, 2005b, 2008). However, the evaluation studies for enterprises in Vietnam are still limited. Therefore, the authors conduct research on the topic "Influence of Overconfidence and cash flow on investment in Vietnam".

\section{Literature Review}

\subsection{Over Confidence}

The analysis of overconfidence relates several branches of the psychology literature (Malmendier \& Tate, 2005b). Having research that defines excessive self-confidence is the difference between a person's belief in self-ability and actual capacity (Pikulina et al., 2017). People often perceive themselves to be more capable than reality and controlling behavior often exceeds their limits (Gervais, Heaton, \& Odean, 2003). There, people often think about themselves higher than others (above average) through positive personal indicators. (Kruger, 1999; Pikulina et al., 2017; Svenson, 1981). The effect of being considered higher than average leads to causal provisions (Malmendier \& Tate, 2005b). Individuals often expect their decisions to be successful in the future. If their decisions are successful, they consider it a result of their decision. However, in contrast when their decisions bring failure, they attribute this to being an unlucky factor (or bad luck) (Feather \& Simon, 1971). This self-serving attribution of outcomes reinforces overconfidence (Malmendier \& Tate, 2005b).
The OverConfidence is kind of Heuristic (Heuristics are rules of thumb, which people use to make decisions in complex, uncertain environments (Gigerenzer \& Gaissmaier, 2011; Tversky \& Kahneman, 1974), in which, people often focus on one aspect of the problem and ignore other factors that may affect their decisions (Abdin, Farooq, Sultana, \& Farooq, 2017; Gigerenzer \& Gaissmaier, 2011). With their investment decisions, people often ignore the principle necessary conditions such as valuation of stocks or financial indicators (Abdin et al., 2017). With the investment decisions of individual investors in the market, it is a behavior that clearly shows the factors of OverConfidence (Abdin et al., 2017; Tversky \& Kahneman, 1974). OverConfidence is evaluated as a heuristic with a characteristic that individual investors often use in decision making (Abdin et al., 2017; Waweru, Munyoki, \& Uliana, 2008).

\subsection{Measurement of Over Confidence}

Malmendier and Tate (2005a) implemented two main approaches that introduced excessive confidence measures. First, the authors define a benchmark for the minimum percentage that CEOs should make their choices in a given year immediately after the trading period. If a $\mathrm{CEO}$ persists in making choices later than the benchmark proposal, this indicates that the CEO is OverConfidence in his ability to keep the company's stock price up and he wants to profit from the price increase expected by holding options. Second, the authors continue to consider ending the optional time. If a CEO is optimistic about the future performance of the company he holds options until expires (usually 10 years), we will classify the CEO as overconfident. Finally, for the CEO underdiversified should avoid buying more equity, the authors classify CEOs as often increasing the company's stock holding rate is OverConfidence (Malmendier \& Tate, 2005a)

Also according to Malmendier \& Tate, the authors also added new measures: OverConfidence measurement was assessed as a major challenge for similar researchers (Malmendier \& Tate, 2005b). According to Malmendier and Tate (2005b), OverConfidence measures 2 aspects: (1) the first is "Revealed beliefs", Overconfidence approaches the CEO's own assessment of the future performance of businesses through transactions with the portfolio of CEOs; (2) OverConfidence approach based on the assessment of outsiders on CEOs:

The first approach (revealed beliefs) requires detailed information about CEO portfolio transactions in the company's stock market/options. Transaction data provides details including the duration, execution price and period of each executive option package. To build a measure of overconfidence, Malmendier and Tate (2005) exploits the 
high degree of diversification that CEOs face. These CEOs receive extensive stock-based compensation, often in the form of restricted stock and non-tradable options. Moreover, their human capital is invested in their company. Thus, even modest risk aversion predicts that CEOs should diversify their portfolios, exercise in-the-money options or sell company stock on a pre-committed schedule. In contrast, some CEOs hold cash as well as buying options instead of selling shares of the company. These CEOs tend to be confident about the future growth of their portfolio. From there, OverConfidence is based on whether the CEO holds options or shares that exceed the average threshold (Malmendier \& Tate, 2005b).

\subsection{The Relationship between Over Confidence and Investment}

There are many researches and statements confirming the relationship between OverConfidence and investment. In the research about Overconfidence and investment, Pikulina et al. (2017) found outrageous confidence and a lack of confidence related to value-maximizing investment options: participants in the overconfidence group and underconfidence selected unsuitable high levels of investment. In this study, it is also shown that moderately Overconfident objects tend to choose more accurate investment than those with higher confidence levels (Pikulina et al., 2017)

At the same time, studies also show the impact of OverConfidence on financial decision making, mainly focusing on financial markets and trading behavior. (Lambert, Bessière, \& N'Goala, 2012). Too confident managers tend to control controlling illusions about investment and the accuracy of judgment, so their decisions tend to overestimate the likelihood of success. They believe that companies will earn good profits and have great growth potential. Since then, excessive investment decisions are prone to arise during operation (He, Chen, \& Hu, 2019).

CEOs who are not too confident or too optimistic do not accumulate risks and tend to delay additional projects (projects are not included in the original plan) until there is accurate information about the project. On the contrary, confident or optimistic CEOs are reluctant to risk before making investment decisions (Gervais et al., 2003). With additional high-risk projects, benefits can be transferred to the CEO as well as shareholders when the investment is effective. However, this under-investment has shifted risks to the bondholders when they face risks. In contrast, CEOs with confidence and optimism must benefit shareholders and increase corporate value as well as reduce the need for compensation options (Gervais et al., 2003; Pikulina et al., 2017). With decisions that are considered safe by these
CEOs, the benefits of CEOs are almost optimal and shareholders do not always encourage (Gervais et al., 2003).

\subsection{The Relationship between Cash Flow, Over Confidence and Investment Decisions}

From an investment policy perspective, the theory shows the CEO's overconfidence affects the decision to invest in businesses in three aspects including overconfidence leading to overinvestment, overconfidence to increase sensitivity of investing in cash flow, and overconfidence can bring investment to its optimal level. Heaton (2002) pointed out that because optimistic directors believe the level of cash flow is higher than reality, many projects will be accepted more. Malmendier and Tate (2005a) modeled cash flow investment sensitivity in companies with overconfident CEOs, and they also led to conclusions like Heaton (Malmendier \& Tate, 2005a). Malmendier and Tate (2008) also point out that overconfident CEOs will overestimate the future rate of return and therefore overinvest in all levels of investment (Malmendier \& Tate, 2005b). There is also research that shows the fact that a director is OverConfidence, not afraid of the risk of investing beyond the optimal level of investment (Goel \& Thakor, 2008).

From a corporate sponsorship policy perspective, the studies have examined variations in funding decisions through psychological biases such as optimism/ overconfidence (Hackbarth, 2008; Heaton, 2002). Their theoretical models predict optimistic and/or overconfident directors who will choose a higher leverage ratio. Hackbarth argues that overconfident directors believe that the volatility of company cash flow is lower than reality and therefore their companies are less likely to experience financial distress than could actually occur (Hackbarth, 2008).

There are many studies that show that cash flow, OverConfidence and investment have a close relationship (Heaton, 2002; Malmendier \& Tate, 2005a). CEOs with overconfidence, large free cash flow and unaffected businesses in the capital market or capital constraint conditions in enterprises tend to overinvest. However, when the cash flow in the business is considered to be limited or not large enough to invest, CEOs tend to limit investment instead of raising capital by issuing shares (CEOs show that the issuance of shares will be information that makes the market underestimate the value of the company according to information asymmetry theory) (Malmendier \& Tate, 2005a). It is the limitation of free cash flow or debt burdens that hinders the overconfident CEOs from overinvesting (Malmendier \& Tate, 2005b). 


\section{Methodology}

\subsection{Research Model}

Referring to previous studies, students make a research model of the thesis as follows:

$$
\begin{gathered}
I N V_{i t}= \\
\alpha_{i t}+\beta_{i t} O C_{i t}+\lambda_{i t} O C_{i t} * C F_{i t}+ \\
\quad \sigma_{i t} \text { Control variable } \text { vat }_{i t}+u_{i t}
\end{gathered}
$$

Equation (1) shows the effect of variables on Investment, where cash flow (CF) is considered an interaction variable to OverConfidence's impact on Investment. Details of

\begin{tabular}{|c|c|c|c|}
\hline Variables & Symbol & Definition & Expected \\
\hline $\begin{array}{l}\text { Dependent } \\
\text { variable: } \\
\text { Investment }\end{array}$ & INV & $\begin{array}{l}\text { Fixed asset purchase } \\
\text { spending }\end{array}$ & \\
\hline \multicolumn{4}{|l|}{$\begin{array}{l}\text { Independen } \\
\text { t variables: }\end{array}$} \\
\hline $\begin{array}{l}\text { OverConfid } \\
\text { ence }\end{array}$ & $\mathrm{OC}$ & $\begin{array}{c}=1 \text { if OverConfidence } \\
\text { (Net Buyer) } \\
=0 \text { if no OverConfidence }\end{array}$ & + \\
\hline \multicolumn{4}{|c|}{ Interaction variable } \\
\hline \multicolumn{2}{|c|}{ Cash Flow } & Cash Flow & + \\
\hline \multicolumn{4}{|c|}{ Control variables } \\
\hline Tobin's Q & Q & $\begin{array}{l}\text { Book value of total } \\
\text { liabilities plus market } \\
\text { value of total } \\
\text { shares/book value of } \\
\text { total assets } \\
\end{array}$ & + \\
\hline Firm size & SIZE & Ln (total assets) & + \\
\hline Growth rate & GROWTH & $\begin{array}{c}\left.\text { (Revenue }_{\mathrm{t}}-\text { Revenue }_{\mathrm{t}-1}\right) \\
\text { /Revenue }_{\mathrm{t}-1}\end{array}$ & + \\
\hline Leverage & LEV & Current liabilitiy/Equity & + \\
\hline
\end{tabular}
variables in the model are described in Table 1.

Table 1: Descriptive the variables

The calculation of OverConfidence is as follows:

Investment: equal to the total purchase of fixed assets in the year and divided by the total assets of the previous year.

OverConfidence is mesured by Net Buyer: The total number of shares purchased and the total number of shares sold by all members of the Board and CEO in the company they are managing. A company is OverConfidence management when the number of years in a net buy position is more than the number of years in the net sale position of the total number of observable years.

CashFlow: is the amount of money earned from business activities (minus costs and tax rates). The fact that the company has large cashflow can motivate $\mathrm{CEO}$ to be more confident in his investment decisions.

Tobin's Q: is the difference between the market value and the book value of the enterprise. With Tobin's Q value greater than 1 will be information that shows that the value of the companies in the market is highly appreciated (Tobin, 1969).

Firm Size: The size of the company represents the large total assets or total capital of the company. Size is measured by taking the loga nepe of total assets. For large companies will tend to diversify the portfolio to limit financial risks. And this diversification makes business investment increase (He, Chen, \& Hu, 2019; Jiang, Cai, Wang, \& Zhu, 2018).

Growth rate: Measured by annual growth of revenue. Companies with high revenue growth will be able to generate large cash flows. Therefore, investment in business development tends to increase

Leverage: Financial leverage is measured by the ratio of liabilities/Equity. The companies have bigger LEV, the more limited the investment (Chen, Sun, \& Xu, 2016; He et al., 2019).

\subsection{Data Collection and Method of Data Analysis}

Secondary database is collected from audited financial statements of enterprises from 2014 to 2018 through FiinPro data system provided by StoxPlus Corporation (Only collect data of non-financial enterprises). With analytical data characteristics for companes listed from 2014 to 2018, the panel data model will be used for analysis. The data, after had been collected, were input to the $\mathrm{R}$ software for analysis. Basic model, such as Fixed effect and Random effect were put in priority. Hausman test was use to find the right model for the real research data between Fixed effect and Random effect (Hausman, 1978).

In case there were some problems in the models, such as autocorrelation, heteroscedasticity, author would use the GLS (Generalized least squares) or robust. The endogeneity, author would use the Difference GMM ( Difference Generalized method of moments) of Arellano - Bond (1991) to fix them. The method of Arellano - Bond was designed to correct the fixed effects implied in the error term of the model due to some unchanged characteristics by time of the studied firms, for example, location and types of business can correlate with explanatory variables in the model. This model is also so used for panel data with a short period of time (time $=5$ years) and a big number of companies because it can make a shock firms' fixed effects, which shows in the error term, reduce by time.

Sagan test or Hansen test and Arellano - Bond test would be use to test the appropriateness of the estimation results of GMM. Sargan test determines the appropriateness of instrumental variables in GMM model. This is a test for over - identification restrictions, of which null hypothesis is that instrumental variables are exogenous. Arellano - Bond test, suggested by Arellano - Bond (Arellano \& Bond, 1991), is used to test for autocorrelation 
of varience in GMM model in first differenced-errors. Therefore, the difference series studied implicitly have linear correlation - AR(1), the testing results are ignored. Autocorrelation - AR(2) is tested on the difference series of error terms to detect autocorrelation of error terms at second order. Hypothesis H0 of Arellano-Bond test does not have autocorrelation and is applied for the remainder of differences.

\section{Results and Discussions}

\subsection{Descriptive}

After the research variables collected will be put into STATA software version 14 for data analysis. Initially, the authors conducted statistics describing the research variables to provide an overview of the indicators of enterprises. With 480 businesses obtained with conditions : having continuous reports from 2014 to 2018. The Investment average was 0.51 in which the largest was 117.98 and the smallest was 0 (no investment). The average cash flow value for enterprise was 0.055 (or $5.5 \%$ ) compared to the annual total asset value. The average Tobin's Q was 1.09 indicates that businesses have good market value. The average financial leverage ratio of enterprises was 0.48 (48\%) -LEV at normal levels. Revenue growth of businesses is at 0.1 (10\% annually). The $10 \%$ revenue growth rate indicates average speed. Detailed parameters of the study variables are described in Table 2.

Table 2: Descriptive

\begin{tabular}{|c|c|c|l|l|c|}
\hline Variable & Obs & Mean & Std. Dev. & \multicolumn{1}{|c|}{ Min } & Max \\
\hline INV & 2,361 & 0.511766 & 3.288667 & 0 & 117.9832 \\
\hline CF & 2,412 & 0.055421 & 0.140014 & -0.5628 & 1.008619 \\
\hline Q & 2,412 & 1.092399 & 0.637998 & 0.084629 & 6.680898 \\
\hline LEV & 2,415 & 0.480371 & 0.230407 & 0 & 0.970612 \\
\hline GROWTH & 2,404 & 0.107615 & 0.32503 & -0.44659 & 0.9702 \\
\hline
\end{tabular}

\subsection{Regression}

Through F-testing in FEM model, the Pooled OLS model does not reflect the true nature of the panel data ( $p$-value of F-test less than 0.05). The results of model selection through Hausman show that the FEM model is consistent with the research data compared to the REM model ( $\mathrm{p}$ value of Hausman test is equal to 0.002 less than 0.05). With the FEM model selected after Hausman test, the author continues to perform autocorrelation and heteroskedasticty tesst. The result of autocorrelation test indicates that the model does not exist autocorrelation ( $p$ value of autocorrelation test is 0.3316 greater than 0.05 ).
However, the FEM model still has the heteroskedasticity so the adjustment models can be solved in this case (Table 3).

To adjusted the heteroskedasticity, the author used two adjusted models (Robust and GLS model). At the same time, the research also uses GMM model to control endogenous in the model.

Table 3: The result of regression

\begin{tabular}{|c|c|c|c|}
\hline & (1) & (2) & (3) \\
\hline $\begin{array}{c}\text { Dependent variable: } \\
\text { Investment }\end{array}$ & $\begin{array}{l}\text { Pooled } \\
\text { OLS }\end{array}$ & FEM & REM \\
\hline \multirow[t]{2}{*}{$\mathrm{OC}$} & $0.298 * *$ & $0.425 * * *$ & $0.358 * *$ \\
\hline & $(0.141)$ & $(0.152)$ & $(0.140)$ \\
\hline \multirow[t]{2}{*}{$\mathrm{OC} * \mathrm{CF}$} & $-0.397 * * *$ & $-0.270 * *$ & $-0.346 * * *$ \\
\hline & $(0.128)$ & $(0.126)$ & $(0.121)$ \\
\hline \multirow[t]{2}{*}{$\mathbf{Q}$} & $-0.179 *$ & 0.581 & -0.191 \\
\hline & $(0.107)$ & $(0.490)$ & $(0.143)$ \\
\hline \multirow[t]{2}{*}{ LEV } & -0.386 & -0.224 & -0.346 \\
\hline & $(0.318)$ & $(0.886)$ & $(0.410)$ \\
\hline \multirow[t]{2}{*}{ GROWTH } & $0.927 * * *$ & $0.749 * * *$ & $0.880 * * *$ \\
\hline & $(0.212)$ & $(0.222)$ & $(0.206)$ \\
\hline \multirow[t]{2}{*}{ SIZE } & 0.0720 & $1.098 * * *$ & $0.113^{*}$ \\
\hline & $(0.0482)$ & $(0.240)$ & $(0.0647)$ \\
\hline \multirow[t]{2}{*}{ Constant } & 0.229 & $-7.264 * * *$ & -0.0426 \\
\hline & $(0.328)$ & $(1.645)$ & $(0.437)$ \\
\hline Observations & 2,357 & 2,357 & 2,357 \\
\hline F-test & & 0.0000 & \\
\hline Hausman test & & 0.0002 & \\
\hline Autocorrelation test & & 0.3316 & \\
\hline Heteroskedasticity test & & 0.0000 & \\
\hline
\end{tabular}

Standard errors in parentheses

$* * * \mathrm{p}<0.01, * * \mathrm{p}<0.05, * \mathrm{p}<0.1$

Table 4: The results of regression with robust models

\begin{tabular}{|c|c|c|c|}
\hline & $(1)$ & $(2)$ & (3) \\
\hline VARIABLES & Robust & GLS & GMM \\
\hline \multirow[t]{2}{*}{$I_{N} V_{t-1}$} & & & $-0.00738 * * *$ \\
\hline & & & $(0.00190)$ \\
\hline \multirow[t]{2}{*}{$\mathrm{OC}$} & $0.425^{* * *}$ & $0.298 * *$ & $0.0910 * *$ \\
\hline & $(0.119)$ & $(0.141)$ & $(0.0452)$ \\
\hline \multirow[t]{2}{*}{$\mathrm{OC} * \mathrm{CF}$} & $-0.270 * * *$ & $-0.397 * * *$ & $-0.151 * * *$ \\
\hline & $(0.0609)$ & $(0.128)$ & $(0.0394)$ \\
\hline \multirow[t]{2}{*}{$\mathbf{Q}$} & $-0.581 * * *$ & $-0.179 *$ & $-0.315^{* *}$ \\
\hline & $(0.174)$ & $(0.106)$ & $(0.123)$ \\
\hline \multirow[t]{2}{*}{ LEV } & -0.224 & -0.386 & $-0.724 * *$ \\
\hline & $(0.458)$ & $(0.318)$ & $(0.308)$ \\
\hline \multirow[t]{2}{*}{ GROWTH } & $0.749 * * *$ & $0.927 * * *$ & $0.437 * * *$ \\
\hline & $(0.270)$ & $(0.212)$ & $(0.0973)$ \\
\hline \multirow[t]{2}{*}{ SIZE } & $1.098 * * *$ & 0.0720 & $0.164 * *$ \\
\hline & $(0.348)$ & $(0.0481)$ & $(0.0747)$ \\
\hline \multirow[t]{2}{*}{ Constant } & $-7.264 * * *$ & 0.229 & -0.128 \\
\hline & $(1.977)$ & $(0.328)$ & $(0.462)$ \\
\hline Observations & 2,357 & 2,357 & 1,873 \\
\hline Number of id & 480 & 480 & 480 \\
\hline $\operatorname{Ar}(2)$ & & & 0.305 \\
\hline Hansen test & & & 0.084 \\
\hline
\end{tabular}

Standard errors in parentheses

$* * * \mathrm{p}<0.01, * * \mathrm{p}<0.05, * \mathrm{p}<0.1$

The results of all three models show that Overconfidence has a positive impact on investment. Besides, the results 
also indicate that the interaction variable Cash flow also has a negative impact on investment. From these results, we can see the similarity with the model that has not been modified FEM above. This indicates the model as well as research data at a sustainable level (reliable) (Table 4).

Overconfidence has the same impact on investment that CEOs are confident to invest more than inconfident CEOs. The confidence of managers in future business results makes investment activities more likely to be implemented (Malmendier \& Tate, 2005b; Pikulina et al., 2017). With confidence in business operations, CEOs believe that their investment decisions yield expected future returns (Lambert et al., 2012). Administrators often expect high growth as well as success in their investment projects. At the same time, with high confident, CEOs continue to intend to invest to increase firm's value as well as enhance the CEO's own value with the board. This problem will make CEOs tended to invest heavily in projects that can be profitable and limit future options (Gervais et al., 2003; Pikulina et al., 2017).

Besides interaction variable Cash flow*Overcoenfidenc have the opposite effect on investment. This result indicates that enterprises with larger cash flows reduce the impact of Overconfidence on investment. Enterprises with large cash flows have a smaller degree of influence on the investment news than enterprises with lower cash flows. CEOs who are confident about the performance of enterprises with large rounds of business development in the future tend to invest less than businesses with lower Cash flow. CEOs of larger Cash flow enterprises in this research have safer investment decisions than low cash flow firms. In contrast, CEOs of enterprises with small CFs have higher expectations for future businesses so they decide to invest more. This result indicates a bad reality in Vietnamese enterprises when the Cash flow is small but CEOs always want to bring their own and firm's values higher, leading to more investment than enterprises with larger Cash flow. The results of this study show to CEOs Overconfidence in enterprises with large Cash flow following effective market theory (Malkiel $\&$ Fama, 1970). And CEOs overconfidence in enterprises have low cash flow according to Kahneman \& Tversky's prospect theory $(1979,2012)$ when investment decisions are easily bias (Kahneman \& Tversky, 2012).

Tobin's Q has a negative impact on investment (negative beta and $p$-value less than 0.05). This result shows that high-firm value often have higher investment levels than lower firm value. Positive effects from large enterprise value make businesses attract the attention of more stakeholders. Therefore, a signal of good business is transmitted passively. Since then, enterprise continue to invest more to expand their business as well as increase their attraction to investors. The results of this study are similar to that of He et al. (2019) and Chen et al. (2016) when they all show the negative impact of Tobin's Q on investment.

Financial leverage has the opposite effect on investment in enterprises (negative beta and p-value less than 0.05). For enterprises have high debt ratios, they will be constrained by capital pressure due to cost of debt. At the same time, this result also shows that enterprises are not willing to trade in costs of debt and business performance. CEOs are not really adventurous with the use of financial leverage to bring business performance. It can be seen that enterprises still follow the classification order theory in mobilizing their investment capital. The results of this study are similar to that of He et al. (2019); Jiang et al. (2018) and Chen et al. (2016) when studying Chinese enterprises.

Revenue growth has a positive impact on investment (positive beta and p-value is less than 0.05). Enterprises have good revenue growth, this is signal that shows business is happening in a positive direction. The increasing market share helps inscrease businesses' competitiveness in the market. Therefore, CEOs will tend to continue investment to expand the market as well as increase the competitiveness of businesses in the market. At the same time, with the strategy of taking market share, it will make the low-competitive enterprises greatly affected (may lead to leaving the market) and bring high-competitive enterprises to continue to get better results in the market. This result is consistent with previous research by Jiang et al. (2018) in China and emerging markets.

Firm size has a positive impact on investment of enterprises (positive beta and p-value less than 0.05). The higher the firm size of enterprises, the more investment levels will increase. It can be seen that the expansion of firm size is always associated with the investment process for production and business activities. At the same time, large-size enterprise will face greater risks than small businesses. Therefore, the diversification of investment portfolios will reduce the risks that may occur in the enterprise. The results of this study are similar to that of $\mathrm{He}$ et al. (2019); Jiang et al. (2018) and Chen et al. (2016) when studying Chinese enterprises.

\section{Conclusion}

With data of 480 enterprises listed on the Vietnam stock exchange from 2014 to 2018 (businesses have continuous reports). Through analysis of panel data with FEM, GLS models, correction of robust and GMM dealing with endogenous problems, analysis results indicate that Overconfidence has a positive impact on Investment. At the same time, the cash flow factor has a limited impact on the investment of enterprises with confident CEOs. From this research result, the study also provides some 
recommendations to help managers and board of directors. can control business investment better. With the regulation of cash flow can limit excessive investment decisions of overconfident CEOs. Especially businesses with overconfident CEOs and low cash flows are more likely to face excessive investment decisions. Therefore, investment decisions should be well controlled in the above case to avoid overinvestment by CEOs.

\section{Reference}

Abdin, S. Z., Farooq, O., Sultana, N., \& Farooq, M. (2017). The impact of heuristics on investment decision and performance: Exploring multiple mediation mechanisms. Research in International Business and Finance, 42, 674-688. https://doi.org/10.1016/j.ribaf.2017.07.010

Akerlof, G. A. (1978). The Market for “Lemon”: Quality uncertainty and the market mechanism. In P. Diamond \& M. Rothschild (Eds.), Uncertainty in Economics (pp. 235-251). https://doi.org/10.1016/B978-0-12-2148507.50022-X

Arellano, M., \& Bond, S. (1991). Some Tests of Specification for Panel Data: Monte Carlo Evidence and an Application to Employment Equations. The Review of Economic Studies, 58(2), 277-297. https://doi.org/10.2307/2297968

Ascioglu, A., Hegde, S. P., \& McDermott, J. B. (2008). Information asymmetry and investment-cash flow sensitivity. Journal of Banking \& Finance, 32(6), 10361048. https://doi.org/10.1016/j.jbankfin.2007.09.018

Chen, X., Sun, Y., \& Xu, X. (2016). Free cash flow, overinvestment and corporate governance in China. PacificBasin Finance Journal, 37, 81-103. https://doi.org/10.1016/j.pacfin.2015.06.003

Feather, N. T., \& Simon, J. G. (1971). Causal attributions for success and failure in relation to expectations of success based upon selective or manipulative control. Journal of Personality, 39(4), 527-541. https://doi.org/10.1111/j.1467-6494.1971.tb00060.x

Gervais, S., Heaton, J. B., \& Odean, T. (2003). Overconfidence, Investment Policy, and Executive Stock Options. SSRN Electronic Journal. https://doi.org/10.2139/ssrn.361200

Gigerenzer, G., \& Gaissmaier, W. (2011). Heuristic Decision Making. Annual Review of Psychology, 62(1), 451-482. 120709-145346

Goel, A. M., \& Thakor, A. V. (2008). Overconfidence, CEO Selection, and Corporate Governance. The Journal of Finance, 63(6), 2737-2784. https://doi.org/10.1111/j.1540-6261.2008.01412.x
Hackbarth, D. (2008). Managerial Traits and Capital Structure Decisions. Journal of Financial and Quantitative Analysis, 43(4), 843-881. https://doi.org/10.1017/S002210900001437X

Hausman, J. A. (1978). Specification Tests in Econometrics. Econometrica, 46(6), 1251-1271. https://doi.org/10.2307/1913827

He, Y., Chen, C., \& Hu, Y. (2019). Managerial overconfidence, internal financing, and investment efficiency: Evidence from China. Research in International Business and Finance, 47, 501-510. https://doi.org/10.1016/j.ribaf.2018.09.010

Heaton, J. B. (2002). Managerial Optimism and Corporate Finance. Financial Management, 31(2), 33-45. https://doi.org/10.2307/3666221

Jiang, F., Cai, W., Wang, X., \& Zhu, B. (2018). Multiple large shareholders and corporate investment: Evidence from China. Journal of Corporate Finance, 50, 66-83. https://doi.org/10.1016/j.jcorpfin.2018.02.001

Kahneman, D., \& Tversky, A. (2012). Prospect Theory: An Analysis of Decision Under Risk. In World Scientific Handbook in Financial Economics Series: Vol. Volume 4. Handbook of the Fundamentals of Financial Decision Making (pp. 99-127). https://doi.org/10.1142/9789814417358_0006

Kruger, J. (1999). Lake Wobegon be gone! The "belowaverage effect" and the egocentric nature of comparative ability judgments. Journal of Personality and Social Psychology, 77(2), 221-232. https://doi.org/10.1037/0022-3514.77.2.221

Lambert, J., Bessière, V., \& N'Goala, G. (2012). Does expertise influence the impact of overconfidence on judgment, valuation and investment decision? Journal of Economic Psychology, 33(6), 1115-1128. https://doi.org/10.1016/j.joep.2012.07.007

Malkiel, B. G., \& Fama, E. F. (1970). Efficient Capital Markets: A Review of Theory and Empirical Work. The Journal of Finance, 25(2), 383-417. https://doi.org/10.1111/j.1540-6261.1970.tb00518.x

Malmendier, U., \& Tate, G. (2005a). CEO Overconfidence and Corporate Investment. The Journal of Finance, 60(6), 2661-2700. https://doi.org/10.1111/j.15406261.2005.00813.x

Malmendier, U., \& Tate, G. (2005b). Does Overconfidence Affect Corporate Investment? CEO Overconfidence Measures Revisited. European Financial Management, 11(5), 649-659. https://doi.org/10.1111/j.13547798.2005.00302.x

Malmendier, U., \& Tate, G. (2008). Who makes acquisitions? CEO overconfidence and the market's reaction. Journal of Financial Economics, 89(1), 20-43. https://doi.org/10.1016/j.jfineco.2007.07.002 
Pikulina, E., Renneboog, L., \& Tobler, P. N. (2017). Overconfidence and investment: An experimental approach. Journal of Corporate Finance, 43, 175-192. https://doi.org/10.1016/j.jcorpfin.2017.01.002

Svenson, O. (1981). Are we all less risky and more skillful than our fellow drivers? Acta Psychologica, 47(2), 143148. https://doi.org/10.1016/0001-6918(81)90005-6

Tobin, J. (1969). A General Equilibrium Approach To Monetary Theory. Journal of Money, Credit and Banking, 1(1), 15-29. https://doi.org/10.2307/1991374
Tversky, A., \& Kahneman, D. (1974). Judgment under Uncertainty: Heuristics and Biases. Science, 185(4157), 1124-1131. https://doi.org/10.1126/science.185.4157.1124

Waweru, N. M., Munyoki, E., \& Uliana, E. (2008). The effects of behavioural factors in investment decisionmaking: A survey of institutional investors operating at the Nairobi Stock Exchange. International Journal of Business and Emerging Markets, 1(1), 24-41. https://doi.org/10.1504/IJBEM.2008.019243 